\title{
Distribution and identity of Bacteria in subarctic permafrost thaw ponds
}

\author{
Paul-Georges Rossi ${ }^{1}$, Isabelle Laurion ${ }^{1}$, Connie Lovejoy ${ }^{2, *}$ \\ ${ }^{1}$ Centre d'études nordiques, Institut national de la recherche scientifique, Centre Eau Terre Environnement, Québec, \\ Quebec G1K 9A9, Canada \\ ${ }^{2}$ Québec-Océan, Département de Biologie and Institut de Biologie Intégrative et des Systèmes (IBIS), Université Laval, \\ Québec, Quebec G1V 0A6, Canada
}

\begin{abstract}
Colored permafrost thaw ponds (thermokarst ponds), are abundant freshwater ecosystems in the subarctic. The ponds can emit significant levels of greenhouse gases, which are drivers of climate change, but little is known of their microbial communities. The ponds are vertically stratified for most of the year with suboxic to anoxic hypolimnia, suggesting varied habitats despite their shallow depths (1 to $4 \mathrm{~m}$ ). Pelagic bacterial communities in 4 contrasting ponds near the coast of Hudson Bay, Quebec, Canada, were investigated by cloning and sequencing the 16S rRNA gene from environmental DNA. Surface and bottom water libraries yielded a total of 109 operational taxonomical units (defined as $97 \%$ sequence similarity) from 261 clones. The majority of clones had their closest matches to other environmental clones originating from freshwater environments, especially lakes. Proteobacteria accounted for the majority of sequences (33\%), followed by Bacteroidetes (19\%), Actinobacteria (13\%), Chlorobi (10\%), Verrucomicrobia (8\%), and Cyanobacteria (7\%). There were large differences in the assemblages inhabiting the different ponds and water layers. Bacteroidetes were predominant at the surface, while Chlorobi were found in bottom waters. Sequences with best matches to known methanotrophic bacteria represented up to $20 \%$ of all sequences. Methanotrophs included Methylobacter psychrophilus, Crenothrix polyspora, and Methylocystis parvus as closest matches. Ordination analysis clearly separated surface and bottom waters, where relatively large quantities of organic matter, low light availability, cool temperatures, and suboxic conditions selected for the distinct communities. The separation of surface waters of different ponds showed that bacterial communities could differ between superficially similar environments. This study illustrates the high diversity in bacterial assemblages occurring in ponds separated by a few meters, and thus, the potentially complex response of thaw pond systems to climate change.
\end{abstract}

KEY WORDS: Bacterial community composition · 16S rRNA clone libraries · Thermokarst lakes

\section{INTRODUCTION}

Because polar and subpolar ecosystems are ice dependent, they are highly vulnerable to global climate change (Parry et al. 2007). Due to the slow incomplete decomposition of organic matter at high latitudes, permafrost soils are estimated to have accumulated approximately $50 \%$ of the global belowground organic carbon stock (McGuire et al.
2009, Tarnocai et al. 2009). Globally, the temperature of the upper permafrost layer has increased by $3^{\circ} \mathrm{C}$ since 1980 (Parry et al. 2007), leading to drastic summer thaw compared to historic records. The decline of permafrost and the mobilization of a large organic carbon pool previously sequestered in tundra soils have the potential to exacerbate climate change through greenhouse gas (GHG) emissions (McGuire et al. 2009, Schuur et al. 2009). 
Lakes and ponds formed by permafrost thaw dominate subarctic and arctic landscapes (Pienitz et al. 2008). In these ecosystems, microbial decomposers have access to large quantities of allochthonous organic matter, which is partly transferred to the atmosphere in the form of the GHGs $\mathrm{CO}_{2}$ and $\mathrm{CH}_{4}$. The $\mathrm{CH}_{4}$ released from Siberian thaw lakes was shown to originate from $\mathrm{C}$ stocks deposited thousands of years ago (Zimov et al. 1997, Walter et al. 2008). The mobilization of ancient carbon as GHG may have significantly contributed to climate warming during the last glacial termination (Shakun et al. 2012) and is thought to represent a significant positive feedback for current warming trends (Walter et al. 2006). Microbial processes such as the breakdown of complex organic substrates, methanogenesis, and methanotrophy determine the net transfer of GHGs to the atmosphere, processes controlled by the substrate availability and oxygen level (or water table; Wagner et al. 2003). Yet little is known of the microbial diversity and ecology of thaw ponds, or how the limnological characteristics could influence microbial activity and gas exchange.

A large fraction of Canada including northern Quebec is underlain by permafrost. The accelerated permafrost thaw associated with climate change has caused soil erosion and an increase in the areal extent of thaw ponds in certain regions (Payette et al. 2004). Subarctic thaw ponds can emit substantial amounts of GHGs, with emissions varying seasonally and over short time scales, depending on pond mixing regimes and vertical structure (Laurion et al. 2010). For example, boreal and tundra lakes release GHGs at higher rates during mixing events in spring and autumn (Phelps et al. 1998, Striegl et al. 2001). Many subarctic ponds are likely thermally stratified for a large fraction of the year due to ice cover in winter, and in summer they are protected from winddriven mixing by their small fetch combined with high turbidity and chromophoric dissolved organic matter (CDOM) enhancing rapid solar heating of the upper surface water. Hence the spring mixing period may be brief (Breton et al. 2009, Laurion et al. 2010) or even absent (I. Laurion unpubl. data). Under stratified conditions, pond bottom waters become suboxic and may accumulate GHGs during summer and winter. Since microbes respire $\mathrm{CO}_{2}$ and some produce or consume $\mathrm{CH}_{4}$, GHG annual net flux would be strongly linked to the microbial community composition. The goals of the present study were first to identify the pelagic bacterial communities of subarctic thaw ponds in the oxygenated surface water and in the hypolimnion where oxygen is depleted, and to assess the influence of pond physicochemical characteristics on community composition. Four contrasting ponds were characterized, and the dominant bacterial groups were identified by cloning and sequencing the 16S rRNA gene from environmental DNA. This is the first environmental $16 \mathrm{~S}$ bacterial gene survey of these very unusual ponds, and taxonomic identification of the major groups was a secondary goal, with the aim of providing robust phylogenies that can be used as references for future studies using short sequences generated from high throughput sequencing technologies.

\section{MATERIALS AND METHODS}

\section{Study site}

Samples were collected from 8 to 14 August 2009 in northeastern Canadian subarctic (Nunavik) at $55^{\circ} 16^{\prime} \mathrm{N}, 77^{\circ} 46^{\prime} \mathrm{W}$, near the village of Whapmagoostui-Kuujjuarapik at the southern limit of discontinuous permafrost (Fig. 1). This region along the Hudson Bay has thousands of shallow (1 to $4 \mathrm{~m}$ deep) thaw ponds, formed as soil thawed below lithalsas (mineral mounds) or organic palsas (when a peat layer was present at pond inception). The ponds belong to the first type, featuring a more defined depression with reduced watershed influence. These ponds are filled with water from precipitation, lack ground water inputs, and are typically highly turbid due to fine silt and clay depositions (Bouchard et al. 2011). They are surrounded by dense shrubs (Betula glandulosa, Salix sp., Alnus sp., Myrica gale) and few trees (Picea mariana, P. glauca, Larix laricina; details in Breton et al. 2009). The striking pattern of pond colors is due to different combinations of particle load from total suspended solids (TSS; Table 1) and CDOM (Watanabe et al. 2011). Four ponds located close to the river Kwakwatanikapistikw (a local Cree name) were selected for the present study (coded KWK and a unique number), and included 1 green pond (KWK-6), 1 black pond (KWK-12), and 2 brown ponds (KWK-1 and KWK-23). Details of the basic limnology and GHG concentrations and fluxes of the ponds are reported in Breton et al. (2009) and Laurion et al. (2010).

\section{Physiochemistry}

Profiles of temperature, dissolved oxygen (DO), $\mathrm{pH}$, and conductivity were recorded with a 600R 


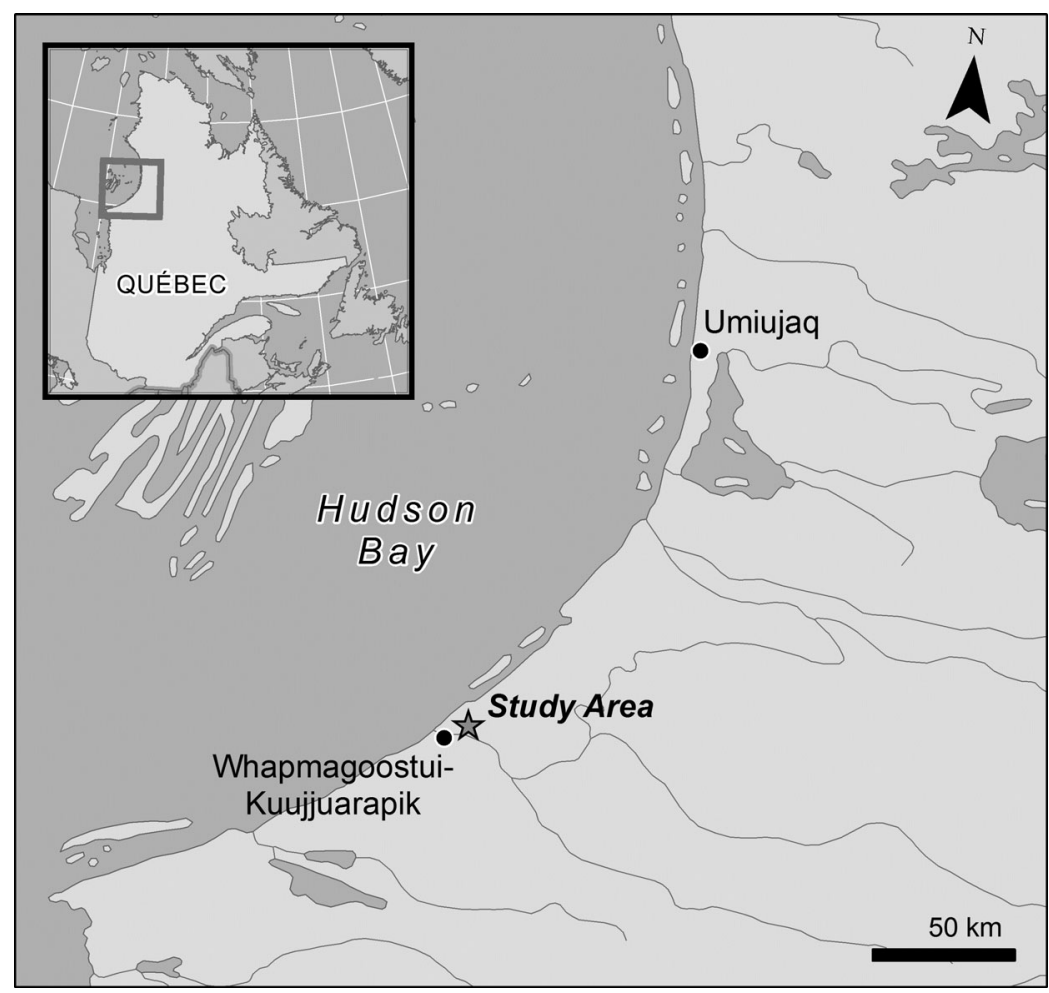

Fig. 1. Geographical position of the study site, indicated by the star $\left(55^{\circ} 16^{\prime} \mathrm{N}\right.$, $77^{\circ} 46^{\prime} \mathrm{W}$ ), in northeastern Canada

multi-parametric probe (Yellow Springs Instrument). The oxygen probe was calibrated at the beginning of each sampling day in water-saturated air with a correction for barometric pressure. Samples were collected at the center of the ponds from a small rubber boat. Surface water was sampled directly into immersed plastic bottles, while bottom water was sampled with a horizontally mounted van Dorn bottle (Wilco) 20 to $40 \mathrm{~cm}$ above the sediment (sampling depth $Z_{\mathrm{s}}$ in Table 1). The collected water was kept in a cooler and transported to the field laboratory within hours. TSS were filtered onto pre-combusted, preweighed GF/F filters (Advantec MFS), which were then oven-dried for $2 \mathrm{~h}$ at $60^{\circ} \mathrm{C}$ and reweighed. Dissolved organic matter (DOM) was characterized from water filtered through pre-rinsed cellulose acetate filters $(0.2 \mu \mathrm{m}$ pore size; Advantec MFS). Dissolved organic carbon (DOC) concentrations were measured using a TOC-5000A carbon analyzer (Shimadzu) calibrated with potassium biphthalate. CDOM absorbance scans were performed from 250 to $800 \mathrm{~nm}$ on a spectrophotometer (Varian Cary 300; details in Laurion et al. 2010). CDOM quantity is defined here by the absorption coefficient at $320 \mathrm{~nm}$ $\left(a_{320}\right)$. Absorption slopes were obtained using an exponential fit between 275 to $295 \mathrm{~nm}\left(S_{275-295}\right)$ and
350 to $400 \mathrm{~nm}\left(S_{350-400}\right)$ as in Helms et al. (2008), and applying the method of Loiselle et al. (2009) between 200 and $650 \mathrm{~nm}$ using a $20 \mathrm{~nm}$ wavelength interval and the open source Scilab software. The resulting set of spectral slopes produces a signature with peaks that can be related to major DOM sources and/or transformations. Total phosphorus (TP) and total nitrogen (TN) samples were fixed with $\mathrm{H}_{2} \mathrm{SO}_{4} \quad(0.15 \%$ final concentration) and digested with potassium persulfate. TP was measured by spectrophotometry as in Stainton et al. (1977) and TN by flow injection analysis (Lachat Instruments). For soluble reactive phosphorus (SRP) measurements, water was filtered as above and analyzed by flow injection analysis. Total dissolved Fe concentrations were measured on filtered water preserved with $\mathrm{HNO}_{3}$, by inductively coupled plasma optical emission spectrometry (ICP-OES; Varian VISTA AX CCD).

Dissolved $\mathrm{CO}_{2}$ and $\mathrm{CH}_{4}$ were determined by the equilibration of $2 \mathrm{l}$ of pond water with $20 \mathrm{ml}$ of ambient air for $3 \mathrm{~min}$, with the headspace sampled in duplicate vials (red stopper Vacutainer) previously flushed with helium and vacuumed. Gas samples were taken within $5 \mathrm{~min}$ after collecting the pond water and kept at $4{ }^{\circ} \mathrm{C}$ until analyzed by gas chromatography (Varian 3800). Aqueous dissolved gas concentrations were calculated according to Henry's Law (details in Laurion et al. 2010).

\section{Microbial characteristics}

To quantify Bacteria and Archaea (BA) and picophototrophs (PP), water samples were fixed with a filtered solution of paraformaldehyde (1\% final concentration) and glutaraldehyde $(0.1 \%$ final concentration) after adding a protease inhibitor (phenylmethanesulfonylfluoride, final concentration of $1 \mu \mathrm{mol}$ $\mathrm{I}^{-1}$; Gundersen et al. 1996) and were kept frozen at $-80^{\circ} \mathrm{C}$ until analysis. BA and PP were counted by flow cytometry (FACSCalibur, Becton-Dickinson). A solution of $0.94 \mu \mathrm{m}$ fluorescent beads (Polysciences) calibrated with trueCOUNT beads (Becton-Dickinson), were added to each sample to estimate cell abundance. BA were labeled with SYBR green I 
Table 1. Limnological properties and color of the 4 study ponds; surface at $0 \mathrm{~m}$ and bottom is indicated by the sampling depth $Z_{\mathrm{s}}$. Water temperature $(T)$, dissolved oxygen (DO), $\mathrm{pH}$, conductivity (Cond), total phosphorus (TP), soluble reactive phosphorus (SRP), total nitrogen (TN), dissolved iron (Fe), dissolved organic carbon (DOC), absorption coefficient of chromophoric dissolved organic matter $(\mathrm{CDOM})$ at $320 \mathrm{~nm}\left(a_{320}\right)$, slope of CDOM spectral absorption between 275 and $295 \mathrm{~nm}\left(\mathrm{~S}_{275-295}\right)$, total suspended solids (TSS), chlorophyll a concentration (chl a), abundance of Bacteria and Archaea (BA) and of picophototrophs

(PP), and dissolved $\mathrm{CO}_{2}$ and $\mathrm{CH}_{4}$ concentrations are given

\begin{tabular}{|c|c|c|c|c|c|c|c|c|c|}
\hline \multirow{3}{*}{$\begin{array}{l}\text { Variable } \\
Z_{\mathrm{s}}\end{array}$} & \multirow{3}{*}{$\begin{array}{c}\text { Units } \\
\mathrm{m}\end{array}$} & \multirow{2}{*}{\multicolumn{2}{|c|}{ KWK-1 (Brown) }} & \multirow{2}{*}{\multicolumn{2}{|c|}{ KWK-6 (Green) }} & \multirow{2}{*}{\multicolumn{2}{|c|}{ KWK-12 (Black) }} & \multirow{2}{*}{\multicolumn{2}{|c|}{ KWK-23 (Brown) }} \\
\hline & & & & & & & & & \\
\hline & & 0 & 2 & 0 & 2.75 & 0 & 2.5 & 0 & 3 \\
\hline$T$ & ${ }^{\circ} \mathrm{C}$ & 19.3 & 7.8 & 15.3 & 9.1 & 17.7 & 7.4 & 15.6 & 5.3 \\
\hline DO & $\mathrm{mg} \mathrm{l}^{-1}$ & 9.6 & 0.2 & 10.4 & 0.1 & 9.1 & 0.2 & 9.2 & 0.2 \\
\hline $\mathrm{pH}$ & & 6.6 & 6.1 & 6.9 & 6.3 & 7.3 & 6.1 & 7.1 & 6.1 \\
\hline Cond & $\mu \mathrm{S} \mathrm{cm} \mathrm{cm}^{-1}$ & 46 & 155 & 61 & 432 & 36 & 249 & 48 & 160 \\
\hline $\mathrm{TP}$ & $\mu \mathrm{g}^{-1}$ & 46 & 176 & 44 & 198 & 24 & 207 & 78 & 432 \\
\hline SRP & $\mu g 1^{-1}$ & 2.9 & 2.4 & 0.9 & na & 0.7 & 1.0 & 5.7 & 46 \\
\hline TN & $\mu g \mathrm{l}^{-1}$ & 251 & 267 & 228 & 389 & 312 & 448 & 228 & 267 \\
\hline $\mathrm{Fe}$ & $\mathrm{mg} \mathrm{l}^{-1}$ & 0.477 & 0.840 & 0.202 & 1.057 & 0.291 & 2.865 & 0.356 & 4.106 \\
\hline DOC & $\mathrm{mg} \mathrm{l}^{-1}$ & 8.1 & 8.3 & 4.1 & 4.2 & 6.0 & 7.4 & 6.3 & 7.5 \\
\hline$a_{320}$ & $\mathrm{~m}^{-1}$ & 42.2 & 44.2 & 12.9 & 19.7 & 26.5 & 63.1 & 32.1 & 87.6 \\
\hline$S_{275-295}$ & $\mathrm{~nm}^{-1}$ & 0.0142 & 0.0130 & 0.0154 & 0.0125 & 0.0139 & 0.0109 & 0.0144 & 0.0107 \\
\hline TSS & $\mathrm{mg} \mathrm{l}^{-1}$ & 8.6 & 89.2 & 8.9 & 13.6 & 1.8 & 73.1 & 18.5 & 144.5 \\
\hline Chl a & $\mu g \mathrm{l}^{-1}$ & 3.5 & 66.4 & 13.4 & 87.2 & 2.2 & 158.9 & 12.3 & 37.1 \\
\hline $\mathrm{BA}^{\mathrm{a}}$ & $10^{6}$ cells ml $^{-1}$ & 12.9 & 37.0 & 11.3 & 18.5 & 9.6 & 38.0 & 12.7 & 24.3 \\
\hline $\mathrm{PP}$ & $10^{6}$ cells ml ${ }^{-1}$ & 0.418 & 1.420 & 0.424 & 0.557 & 0.094 & 2.873 & 0.377 & 0.662 \\
\hline $\mathrm{CO}_{2}$ & $\mu \mathrm{M}$ & 58.0 & 405 & 27.3 & 421.8 & 55.3 & 761.2 & 52.8 & 570.1 \\
\hline $\mathrm{CH}_{4}$ & $\mu \mathrm{M}$ & 0.4 & 93.8 & 0.5 & 145.2 & 0.3 & 259.0 & 0.3 & 131.6 \\
\hline
\end{tabular}

(Sigma-Aldrich) and counted for 2 min at a low flow rate $\left(12\right.$ to $15 \mu \mathrm{l} \mathrm{s}{ }^{-1}$ ), and PP (cells with chlorophyll fluorescence) were counted without staining for 3 to $4 \mathrm{~min}$ at a high flow rate $\left(50\right.$ to $\left.60 \mu \mathrm{s} \mathrm{s}^{-1}\right)$. Only populations with sizes close to ca. 1 to $3 \mu \mathrm{m}$ were counted (i.e. larger cells would be out of range for the settings used).

Chlorophyll a $(\mathrm{chl}$ a) concentrations were determined from water samples filtered onto GF/F filters (Advantec MFS). Filters were kept frozen at $-80^{\circ} \mathrm{C}$ until pigments were extracted by placing the filters in boiling $95 \%$ ethanol for 5 min followed by $1 \mathrm{~h}$ extraction at $4^{\circ} \mathrm{C}$ (Nush 1980). Chl a fluorescence was measured with a spectrofluorometer (Varian Cary Eclipse) before and after acidification (to correct for the interference by pheophytin), and the concentration was estimated using the equation of Jeffrey \& Welschmeyer (1997).

For molecular analyses, cells were collected by filtration using a peristaltic pump (Masterflex). Water samples passed through $3 \mu \mathrm{m}$ pore size, $47 \mathrm{~mm}$ polycarbonate filters (Nuclepore) followed by $0.22 \mu \mathrm{m}$ Sterivex units (Millipore). Both filters were stored in a buffer solution (40 mM EDTA; 50 mM Tris, $\mathrm{pH}$ 8.3; $0.75 \mathrm{M}$ Sucrose) at $-80^{\circ} \mathrm{C}$. Genomic DNA was extracted as in Díez et al. (2001). Briefly, lysozyme
(1 $\mathrm{mg} \mathrm{ml}^{-1}$ final concentration), Proteinase $\mathrm{K}(0.2 \mathrm{mg}$ $\mathrm{ml}^{-1}$ final concentration), and $200 \mu \mathrm{l}$ of $10 \%$ sodium dodecyl sulfate were used to liberate cellular contents. The lysate from the Sterivex was recovered using a syringe. Then, the lysate was extracted twice with a mixture of phenol, chloroform, and isoamyl alcohol (25:24:1, pH 8) and once with chloroform and isoamyl alcohol mix (24:1). DNA was then precipitated from aqueous phase overnight at $4{ }^{\circ} \mathrm{C}$ using isopropanol and ammonium acetate. Finally, TE buffer (Tris-EDTA: $10 \mathrm{mM}$ Tris-HCl, $1 \mathrm{mM}$ EDTA) was used to resuspend the DNA. DNA concentrations were measured with PicoGreen reagent (Molecular Probes) using a TBS-380 fluorometer (Promega Biosystems).

Partial bacterial rRNA 16 S genes were amplified using the universal primer 1492R (5'-GGT TAC CTT GTT ACG ACT T-3') and the bacteria specific primer 8F (5'-AGA GTT TGA TCC TGG CTC AG$\left.3^{\prime}\right)$ from dilutions of extracted DNA (1, 0.1, and 0.01 ), providing different template concentrations, to address potential primer competition. PCR conditions were previously described by Harding et al. (2011). PCR amplicons were checked by gel electrophoresis. Clone libraries were constructed from the combined amplicons of both fractions $(>3 \mu \mathrm{m}$ and 
0.2 to $3 \mu \mathrm{m})$. PCR products from each sample dilution were pooled prior to purification using a QIAquick PCR purification kit (Qiagen). The purified PCR products were then cloned using Strataclone PCR cloning kit (Agilent Technologies). Eight clone libraries were constructed representing the surface and bottom waters of the 4 ponds. Correct size amplicons were sequenced in both directions using primers for the vectors M13 by the Plateforme de Séquençage et de Génotypage des Génomes (Centre Hospitalier de l'Université Laval, QC, Canada), using an ABI 3730xl system (Applied Biosystems), which included a purification step. The 2 sequences for 1 clone were aligned and merged using Bioedit software (v.7.1.3). A total of 341 clones were sequenced, from which 330 were retained for further analysis after quality screening, short sequences, and those with multiple non-identified nucleotides (Ns) were discarded.

All sequences were aligned using the align option of the Greengenes web application (DeSantis et al. 2006) to quickly check for sequences showing poor quality alignments ( $<75 \%$ identity). The remaining sequences were checked for chimeras using the Chimera check with the Bellerophon option of the Greengenes web application (Huber et al. 2004). The putative chimeras were checked manually as described by Harding et al. (2011). Remaining sequences were compared to the NCBI GenBank nucleotide collection database using the Megablast program of BLASTn (Altschul et al. 1990) to identify their closest match. The source environment of matches was estimated according to the sources of the 3 best matches (96 to $99 \%$ similarity). Sequences belonging to $16 \mathrm{~S}$ rRNA genes of chloroplasts or mitochondria were discarded, and following this additional screening, 261 sequences were retained (KWK-1S: 30; KWK-1B: 42; KWK-6S: 33; KWK-6B: 32; KWK-12S: 33; KWK12B: 26; KWK-23S: 34; KWK-23B: 31). The nucleotide sequences were deposited in GenBank (accession numbers JN656715 to JN656931).

To assess the relative occurrences of bacterial phyla within each sample, surface, bottom, and whole environment composite, the sequences were classified using the program Classifier from the Ribosomal Database Project (RDP) II (Wang et al. 2007). Sequences were grouped by phyla to construct phylogenetic trees using ClustalX v.2.1 (Larkin et al. 2007 ) and to identify similar sequences from different ponds (not shown). Sequences with $\geq 97 \%$ similarity were grouped as operational taxonomical units (OTUs) using Mothur v.1.14.0 (Schloss et al. 2009) through a PHYLIP v.3.67 Jukes-Cantor distance matrix (Felsenstein 1989). This software was also used to plot the rarefaction curve (not shown) of thaw ponds libraries.

\section{Community and limnological comparisons}

Differences between the communities were assessed using the UniFrac significance test from the weighted algorithm of Fast UniFrac software package (Hamady et al. 2010). Clones matching Bacteria with known functions were identified from the clone library, and their occurrences were visualized using a heatmap. For that, a data table with relative abundance of clones related to functional group members in each sample. The following values were used to assess the influence of limnological variables on the communities: chl $a, \mathrm{BA}, \mathrm{PP}, \mathrm{SRP}, \mathrm{TP}, \mathrm{TN}, \mathrm{Fe}, \mathrm{TSS}$, DOC, $a_{320}, S_{275-295}$, dissolved $\mathrm{CO}_{2}$ and $\mathrm{CH}_{4}$ concentrations, water temperature, conductivity, DO, and $\mathrm{pH}$ after $z$-score transformation (Ramette 2007). These data were first tested separately for normal distribution using Shapiro-Wilk test in PAST (Hammer et al. 2001). According to the expected differences between surface and bottom physicochemistry, some variables (BA, SRP, DO, TSS, and Fe) departed from normality, and therefore multivariate normality was not assessed. To select the best method for interpreting the environmental data, we ran a detrended correspondence analysis using CANOCO 4.5 (ter Braak \& Smilauer 1998). The first gradient was ca. 4.8 , indicating that the unimodal methods were the most appropriate. Following this result, a canonical correspondence analysis (CCA; scaling type 1) was performed using PAST software and standardized environmental variables. Due to the low number of samples, it was inconclusive whether there was autocorrelation among environmental variables and we therefore chose to include all of them in the CCA.

\section{RESULTS}

\section{Physicochemical properties}

The maximum pond depths were approximately $2.2,3.2,2.85$, and $3.4 \mathrm{~m}$, respectively, for KWK-1, -6, -12 , and -23 , while the pond area were respectively $167,265,213$, and $259 \mathrm{~m}^{2}$, as estimated from a highresolution Quickbird image taken in 2006 (I. Laurion unpubl. data). All ponds were thermally stratified at the time of sampling, resulting in marked differences in most characteristics between surface and bottom 
waters (Table 1). The calculation of the Schmidt number (Lorke \& Peeters 2006) indicates higher water column stability for KWK-12 and -23 (9.7 and $9.0 \times 10^{-4} \mathrm{~g} \mathrm{~cm}^{-1}$, respectively) compared to KWK-1 and $-6\left(7.7\right.$ and $\left.5.5 \times 10^{-4} \mathrm{~g} \mathrm{~cm}^{-1}\right)$. The water column is thermally stratified for most of the year in these ponds, as indicated from thermistors installed at surface and bottom of KWK-1 and -12 from August 2009 to August 2010, where the water column mixed for only $10 \mathrm{~d}$ in September/October, and suggesting that anoxia is a common feature for this type of turbid and humic environment, both under the ice in winter and in the hypolimnia in summer. Both ponds remained ice-covered for approximately $200 \mathrm{~d}$.

The surface $\mathrm{pH}$ of all the ponds was circumneutral, with slightly more acidic bottom waters. Surface waters had lower conductivities (36 to $61 \mu \mathrm{S} \mathrm{cm}{ }^{-1}$ ) compared to bottom waters (155 to $432 \mu \mathrm{S} \mathrm{cm}^{-1}$ ), with maximum conductivity recorded in pond KWK-6. Surface waters were well oxygenated (above 100\% saturation in KWK-1 and -6, above $92 \%$ in the other 2 ponds), whereas hypolimnia were suboxic and likely anoxic given the vertical stability and trophic level of ponds (values were below the detection limit of the YSI probe; $0.2 \mathrm{mg} \mathrm{l}^{-1}$ ). Bottom waters were richer in TP compared to surface waters, with maximum concentrations in KWK-23. This pond also had the highest SRP concentrations and higher SRP at the bottom, while SRP was more similar in surface and bottom waters for the other ponds. TN was similar in surface and bottom waters of KWK-1 and -23, while concentrations were higher at the bottom of KWK-6 and -12. Iron concentrations were always higher in bottom waters, with maximal values reaching $4.1 \mathrm{mg}$ $\mathrm{l}^{-1}$ in KWK-23.

The highest surface water DOC and CDOM were obtained in KWK-1, with similar values in surface and bottom waters, and the lowest values were in KWK-6. Ponds KWK-12 and -23 had intermediate DOC and CDOM at the surface, and about 2.5 times higher CDOM at the bottom. The higher $S_{275-295}$ values suggest lower molecular weight DOM in surface waters, especially in KWK-6, and the largest difference with depth was noted in pond KWK-23. However, the chemistry of suboxic bottom waters possibly generates unusual chromophoric compounds (especially when there is a lot of $\mathrm{Fe}$ ) that would explain such low $S_{275-295}$ and high $a_{320}$. The spectral slope signatures (large peaks at ca. 385 and $425 \mathrm{~nm}$; not shown) suggest a larger contribution of peat decomposition in KWK-12 and -23 bottom waters (also reflected in surface waters compared to the other 2 ponds), consistent with the higher DOM absorptivity $\left(a_{320} / \mathrm{DOC}\right)$. The spectral slope signature also suggests a larger contribution of autochthonous DOM at the surface of KWK-6 and -23, consistent with the higher chl a concentrations (Table 1).

In surface waters, dissolved concentrations of $\mathrm{CO}_{2}$ and $\mathrm{CH}_{4}$ were low, although supersaturating, and similar among ponds (Table 1). Concentrations were greater and more variable deeper in the water column. The greatest accumulation of both gases was observed at the bottom of pond KWK-12.

\section{Microbial abundance and biomass}

Mean $( \pm \mathrm{SD})$ surface BA concentrations from flow cytometry averaged $11.6 \times 10^{6} \pm 1.5 \times 10^{6} \mathrm{cells} \mathrm{ml}^{-1}$ and were less variable compared to bottom waters, where the average concentration was $29.5 \times 10^{6} \pm 9.6$ $\times 10^{6}$ cells ml ${ }^{-1}$ (Table 1 ). The highest concentrations were found in KWK-1 and -12 bottom waters. PP from flow cytometry were much less abundant than BA, with higher concentrations in the bottom waters, except for pond KWK-6. The analysis of PP cytograms indicated the presence of 6 populations (not shown), with some only present in bottom waters. The chl a concentrations ranged from 2.2 to $13.4 \mu \mathrm{g}$ $\mathrm{1}^{-1}$ in surface waters, with very high values in bottom waters (up to $158.9 \mu \mathrm{g} \mathrm{l}^{-1}$ in KWK-12), and was significantly correlated to PP (Pearson correlation $\mathrm{r}=$ 0.902, $\mathrm{p}=0.002$ ).

\section{Bacterial community composition}

The 16S rRNA gene clone libraries $(n=8)$ provided an indication of the bacterial diversity among thaw ponds, and sequences from taxa potentially involved in $\mathrm{CH}_{4}$ consumption were retrieved (see below). Rarefaction curves estimated from OTUs defined at the $97 \%$ similarity level did not reach a plateau (not shown), indicating that the system was under sampled. In total, we delineated 109 OTUs from the 261 sequences (Table 2). The single most abundant OTU (27 clones) was found in the bottom waters of all 4 ponds (Fig. 2) and was 96 to $97 \%$ similar to the cultured Pelodictyon phaeoclathratiforme BU-1 (NC 011060) in the phylum Chlorobi. No single OTU or species was common to all surface samples (Fig. 2). The second most abundant OTU (14 clones) was found at the surface of 3 ponds, and was $97 \%$ similar to the cyanobacterium Anabaena flos-aquae (GenBank accession AJ630420). Another common OTU, with nearest cultured matches 97 to $99 \%$ similar to 
Table 2. Closest environmental matches to the major classes of Bacteria from Megablast against the NCBI non-redundant nucleotide (nr/nt) data base (1 July 2012). All 'best' matches were usually $\geq 98 \%$ similar over the ca. 1500 bp sequences. The number of times a particular environment was found as a source is given in parentheses

\begin{tabular}{|c|c|c|c|}
\hline Phylum & $\begin{array}{l}\text { Type of } \\
\text { sample }\end{array}$ & $\begin{array}{l}\text { No. of } \\
\text { clones }\end{array}$ & Environment of the closest matches \\
\hline Bacteroidetes & $\begin{array}{l}\text { Surface } \\
\text { Bottom }\end{array}$ & 20 & $\begin{array}{l}\text { Oligotrophic lake (1), wastewater (6), river (7), arctic lake (6), acidic bog lake } \\
(8), \text { mine (2) } \\
\text { Acidic lake (7), suboxic pond (3), acidic bog lake (2), wastewater (1), sulfidic } \\
\text { karst system (1), rivulet (1), clinical sample (1), high altitude soil (1), arctic } \\
\text { lake (2), soil (1) }\end{array}$ \\
\hline Betaproteobacteria & $\begin{array}{l}\text { Surface } \\
\text { Bottom }\end{array}$ & 24 & $\begin{array}{l}\text { Nival lake (1), lake (3), river bay (4), river (3), arctic lake (4), wastewater (1), } \\
\text { oligotrophic lake (6), acidic lake (2) } \\
\text { Glacier (2), high alpine wetland (1), bay sediments (1), eutrophic lake (6), } \\
\text { river bay (4), river (3), freshwater metazoan-associated bacteria (2), acidic bog } \\
\text { lake (1) }\end{array}$ \\
\hline Actinobacteria & $\begin{array}{l}\text { Surface } \\
\text { Bottom }\end{array}$ & 28 & $\begin{array}{l}\text { Lake (16), bog lake (1), river (1), river bay (4), eutrophic stratified reservoir (2), } \\
\text { eutrophic lake (1), altitude oligotrophic lake (2), oligotrophic lake (1), } \\
\text { lake (3), river bay (2), bog lake (1), oligotrophic lake (1) }\end{array}$ \\
\hline Chlorobi & $\begin{array}{l}\text { Surface } \\
\text { Bottom }\end{array}$ & $\begin{array}{c}0 \\
17\end{array}$ & $\begin{array}{l}\text { Not applicable } \\
\text { High altitude meromictic lake (17) }\end{array}$ \\
\hline Verrucomicrobia & $\begin{array}{l}\text { Surface } \\
\text { Bottom }\end{array}$ & $\begin{array}{l}12 \\
8\end{array}$ & $\begin{array}{l}\text { Oligotrophic lake (5), alpine lake (1), acidic bog lake (2), sulfidic cave stream } \\
\text { (1), Siberian peat bog (3) } \\
\text { Oligotrophic lake (3), mine (1), Siberian peat bog (1), wastewater (1), acidic } \\
\text { bog lake (1), sulfidic cave stream (1) }\end{array}$ \\
\hline Gammaproteobacteria & $\begin{array}{l}\text { Surface } \\
\text { Bottom }\end{array}$ & $\begin{array}{c}3 \\
15\end{array}$ & $\begin{array}{l}\text { Arctic glacier (1), phyllosphere (1), Bering Sea (1) } \\
\text { Acidic altitude wetland (6), arctic wetland soil (8), Bering Sea sediments (1) }\end{array}$ \\
\hline Cyanobacteria & $\begin{array}{l}\text { Surface } \\
\text { Bottom }\end{array}$ & $\begin{array}{c}16 \\
1\end{array}$ & $\begin{array}{l}\text { Boreal eutrophic lake (12), altitude lake (2), Baltic Sea (2) } \\
\text { Eutrophic reservoir }\end{array}$ \\
\hline Alphaproteobacteria & $\begin{array}{l}\text { Surface } \\
\text { Bottom }\end{array}$ & $\begin{array}{l}5 \\
5\end{array}$ & $\begin{array}{l}\text { Antarctic pond (1), soil (1), river bay (2), acidic bog lake (1) } \\
\text { Acidic bog lake (1), river bay (1), lake (2), altitude oligotrophic lake (1) }\end{array}$ \\
\hline Unclassified bacteria & $\begin{array}{l}\text { Surface } \\
\text { Bottom }\end{array}$ & $\begin{array}{l}1 \\
9\end{array}$ & $\begin{array}{l}\text { Lake } \\
\text { Groundwater (1), sulfidic cave stream (1), acidic lake (4), meromictic lake (1), } \\
\text { suboxic pond (2) }\end{array}$ \\
\hline Deltaproteobacteria & $\begin{array}{l}\text { Surface } \\
\text { Bottom }\end{array}$ & $\begin{array}{l}1 \\
8\end{array}$ & $\begin{array}{l}\text { Soil } \\
\text { Iron-rich freshwater seep (6), iron-rich snow (1), deglaciated soil (1) }\end{array}$ \\
\hline Acidobacteria & $\begin{array}{l}\text { Surface } \\
\text { Bottom }\end{array}$ & $\begin{array}{l}0 \\
7\end{array}$ & $\begin{array}{l}\text { Not applicable } \\
\text { Meromictic lake (6), reed bed rhizosphere (1) }\end{array}$ \\
\hline Planctomycetes & $\begin{array}{l}\text { Surface } \\
\text { Bottom }\end{array}$ & $\begin{array}{l}5 \\
0\end{array}$ & $\begin{array}{l}\text { Lake sediment (2), peat bog (1), compost (1), wastewater (1) } \\
\text { Not applicable }\end{array}$ \\
\hline Others & $\begin{array}{l}\text { Surface } \\
\text { Bottom }\end{array}$ & $\begin{array}{l}5 \\
4\end{array}$ & $\begin{array}{l}\text { Tundra soil (1), wastewater (2), lake (1), deglaciated soil (1) } \\
\text { Aquifer (2), wastewater (1), soil (1) }\end{array}$ \\
\hline
\end{tabular}

the Polynucleobacter necessarius CP000655 (Betaproteobacteria), was found both in surface and bottom waters of all ponds, except KWK-6 surface water.

A regional view of the subarctic thaw ponds is indicated by the attribution of major phyla from the 8 libraries identified using the RDP classifier (Fig. 3; first bar). Seven phyla contributed $>5 \%$ of the total sequences, with Proteobacteria accounting for the greatest percentage of sequences (33.3\%). Among the Proteobacteria, Betaproteobacteria accounted for nearly $17 \%$, and Gammaproteobacteria were common $(6.9 \%)$. The next most abundant phylum was the Bacteroidetes (19.2\%), followed by Actinobacte- ria $(13.4 \%), \quad$ Chlorobi $(10.3 \%), \quad$ Verrucomicrobia $(7.7 \%)$, and Cyanobacteria $(6.5 \%)$.

There were differences in the relative representation of major phyla among pond libraries. Betaproteobacteria represented the major class from the surface waters of KWK-1 and -12 with 30 and $27.3 \%$ of the clones in their respective libraries. Bacteroidetes were the second most common with 20 and $24.2 \%$ of clones in the same libraries. Many KWK-6 surface water sequences were also Bacteroidetes (30.3\%), but Cyanobacteria accounted for a similar proportion of the sequences $(27.3 \%)$. The sequences from the surface water of KWK-23 were mostly Actinobacteria 


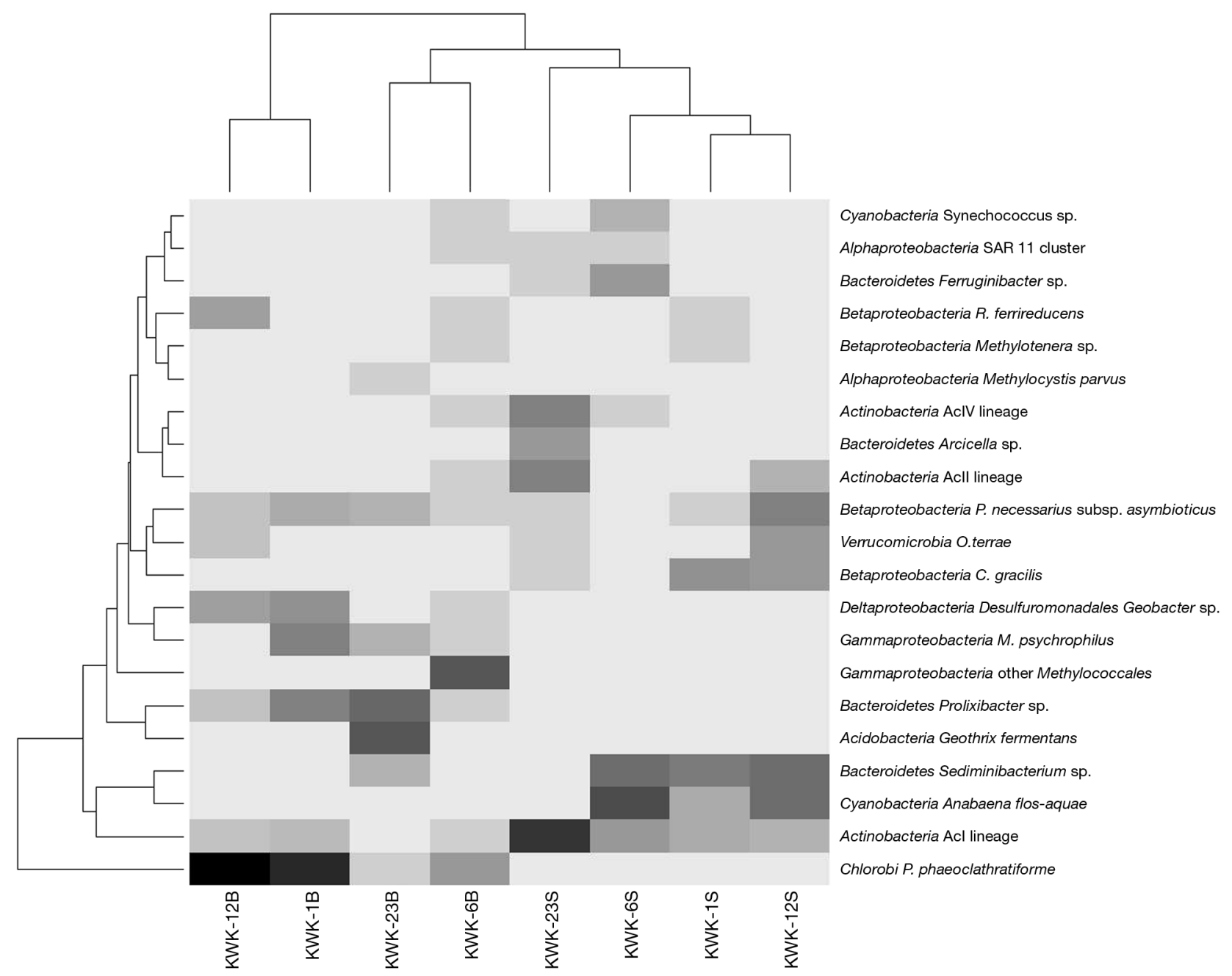

Fig. 2. Relative abundance, represented by a heatmap, of associated species in the samples. Rows and columns were sorted according to their similarities. Shades of gray indicate proportion of total sequences represented by the specific taxa. The maximum proportion was 0.4 or $40 \%$ of the sequences in that sample. KWK ponds are referred to by their identification number.

S: surface; B: bottom

$(52.9 \%)$, with Bacteroidetes $(17.6 \%)$ also present. Pond KWK-1 bottom water sequences included Chlorobi (28.6\%), Betaproteobacteria (16.7\%), and Bacteroidetes $(16.7 \%)$ related sequences. KWK-12 bottom water libraries were mostly Chlorobi (42.3\%), with Betaproteobacteria (15.4\%) and Verrucomicrobia $(15.4 \%)$ sequences accounting for much of the remainder of the library. Pond KWK-6 bottom water sequences were a mix of Gammaproteobacteria (25\%) and Betaproteobacteria (15.6\%) and other groups. Finally, Bacteroidetes (35.5\%) and Acidobacteria-related sequences $(19.4 \%)$ were the most represented sequences recovered from the KWK-23 bottom water library (Fig. 3).

We found 15 clones related to methanotrophic bacteria. Ten clones were closest to the Gammapro- teobacteria species Methylobacter psychrophilus strain Z-0021 (NR025016.1; 95 to 99\% similarity). They were found in KWK-1, -6 , and -23 . Four clones were closest to the cultured species Crenothrix polyspora (DQ295895.1; but with only 94\% similarity). This sequence was only found in KWK-6 bottom water. In KWK-23 bottom water, a sequence 99\% similar to Methylocystis parvus (AF150805.1) was found.

Overall, combining all surface and all bottom communities (Fig. 3, last 2 bars) highlighted the general differences among the communities from oxic and suboxic waters. Surface communities with Bacteroidetes, Actinobacteria, Betaproteobacteria, and Cyanobacteria differed from bottom waters that also included Chlorobi and Acidobacteria and greater proportions of Gammaproteobacteria and Deltapro- 


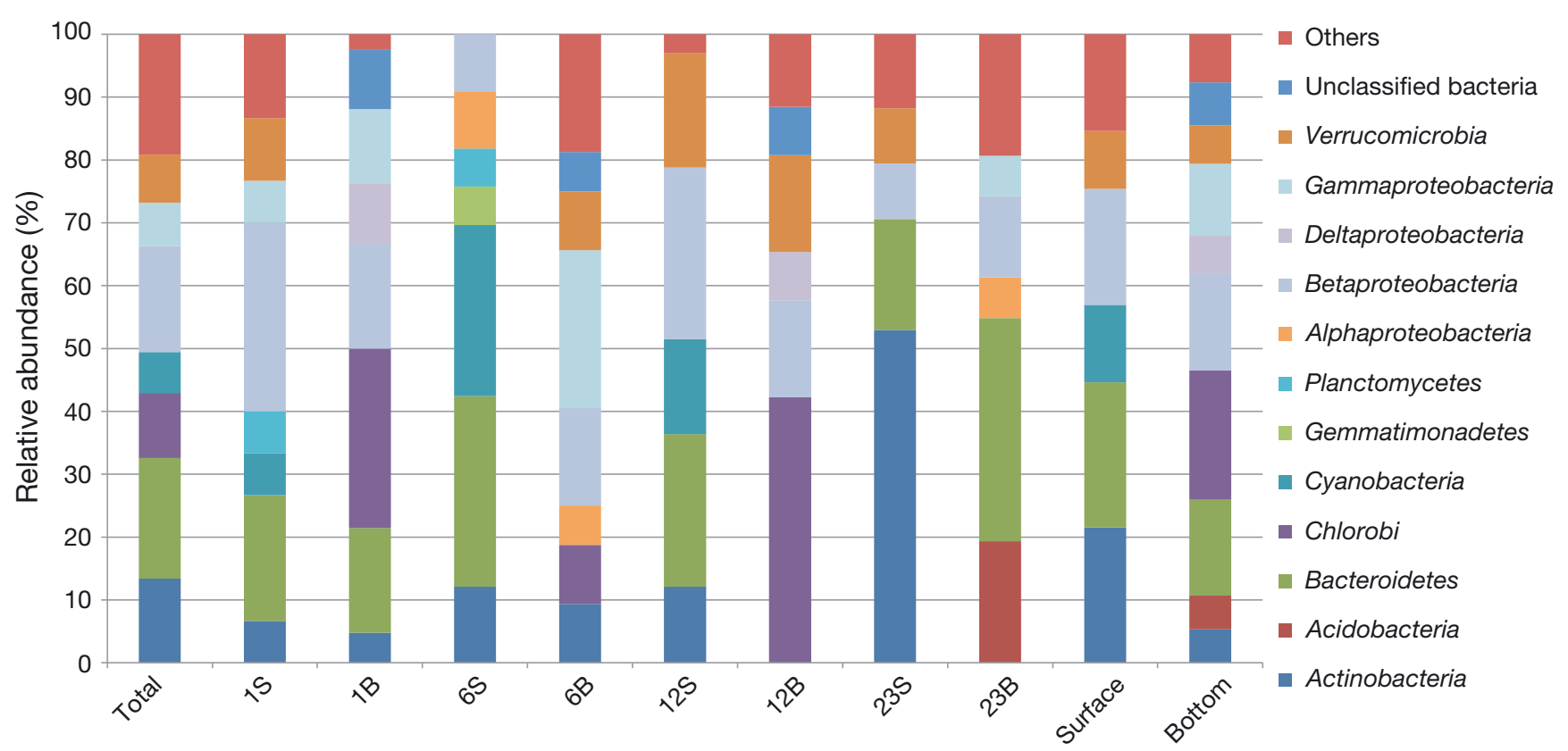

Fig. 3. Relative abundance of the different phyla obtained with the RDP classifier. 'Total' bar represents the combined results of all libraries, KWK ponds are referred to by their identification number, and the 'Surface' and 'Bottom' bars represent the combined samples. Phyla accounting for less than $5 \%$ were combined under 'Others'. S: surface; B: bottom

teobacteria (Fig. 3, Table 2). The proportion of unclassified bacteria was relatively low (10 clones), and most of these were from bottom waters.

Analysis of the sequences at finer taxonomic levels showed that $94 \%$ of the Betaproteobacteria from surface waters of KWK-1 and -12 were in the order Burkholderiales, with similarity to the cultured species Curvibacter gracilis (Comamonadaceae), and Polynucleobacter necessarius (Burkholderiaceae). The Bacteroidetes from KWK-1 and -12 surface waters (3 distinct OTUs) were represented by the order Sphingobacteriales, with the genus Sediminibacterium accounting for $75 \%$ of these. The Bacteroidetes from KWK-6 surface water separated into 6 OTUs and were mostly Sediminibacterium and Ferruginibacter (Sphingobacteriales). The second most common phylum at the surface of KWK-6 was Cyanobacteria, mainly Anabaena and Synechococcus. The bacterial community at the surface of KWK-23 was dominated by the order Actinomycetales in the phylum Actinobacteria.

All Chlorobi clones in hypolimnetic waters of KWK-1 and -12 were $\geq 98 \%$ similar to Pelodictyon phaeclatathratiforme (Fig. 2). Betaproteobacteria, the second most frequent phylum in these samples, were mostly in the Burkholderiales. Clones related to Polynucleobacter necessarius from the Burkholderiaceae were found in both samples. Oxalobacteraceae represented by Rhodoferax related clones were also recovered from KWK-1 and -12. Most (87.5\%) Gammaproteobacteria from the KWK-6 bottom community were in the Methylococcaceae represented by clones with affinities to the methanotroph Methylobacter psychrophilus. Sequences similar to M. psychrophilus were also the only Gammaproteobacteria found in KWK-1 and -23 bottom waters. Bacteroidetes retrieved from the KWK-23 bottom community were represented by the sequences closest to the genera Sediminibacterium and Prolixibacter. Clones related to Geothrix fermentans in the Acidobacteria were also recovered from KWK-23. Another clone from this phylum was retrieved from KWK-6 bottom water.

\section{Origins of best matches}

The closest matches to the majority of the sequences were to clones from other environmental surveys. Over $75 \%$ of the closest matches of both surface and bottom waters were originally reported from freshwater environments (Table 2), most commonly from lakes. Among these lakes, over one-third of the nearest matches were reported from either summer stratified or meromictic lakes. The closest matches originally reported from soil environments represented ca. $9 \%$ of the total clones, with fewer matches with the surface than with the bottom waters. One-third of 
the closest matches to our sequences had been previously reported from cold ecosystems such as high altitudes and polar environments.

\section{Multivariate analysis}

To assess the significance of the differences among sample communities, we statistically weighted the differences using pairwise comparisons with UniFrac. The surface communities showed significant ( $p$-values from 0.001 to 0.01 ) to highly significant ( $p<$ 0.001) differences compared to bottom communities. Comparisons of surface communities did not show significant differences between KWK-1 and -12 or between KWK-6 and -12. Marginally significant (pvalues from 0.01 to 0.05 ) differences were found between KWK-1 and -6. Significant to highly significant differences were found comparing KWK-23 sur- face community to others. The comparisons of bottom waters were marginally (KWK-1 compared to KWK6) to highly significant among ponds, except between KWK-1 and -12, where the difference was not significant. We carried out a community correspondence analysis (CA) (with OTU abundances, not shown) which also separated surface and bottom.

The most significant variables from CCA when tested alone were TP, $S_{275-295}, \mathrm{CO}_{2}, \mathrm{CH}_{4}, T$, conductivity, DO, pH, and TSS. Some variables showed multicollinearity, especially $\mathrm{CO}_{2}, \mathrm{pH}$, and $T$ (Fig. 4). Surface samples were clearly separated from bottom samples, and most environmental variables seemed to load along this separation, especially $\mathrm{CH}_{4}$ and DO. The group formed by surface samples KWK-1, -6, and -12 was characterized by higher DO, $T, \mathrm{pH}$, and $S_{275-295}$, and lower $\mathrm{CO}_{2}, \mathrm{CH}_{4}$, and conductivity, with biological influences from/on Anabaena, Synechococcus, Opitutus, Curvibacter gracilis, and Sedi-

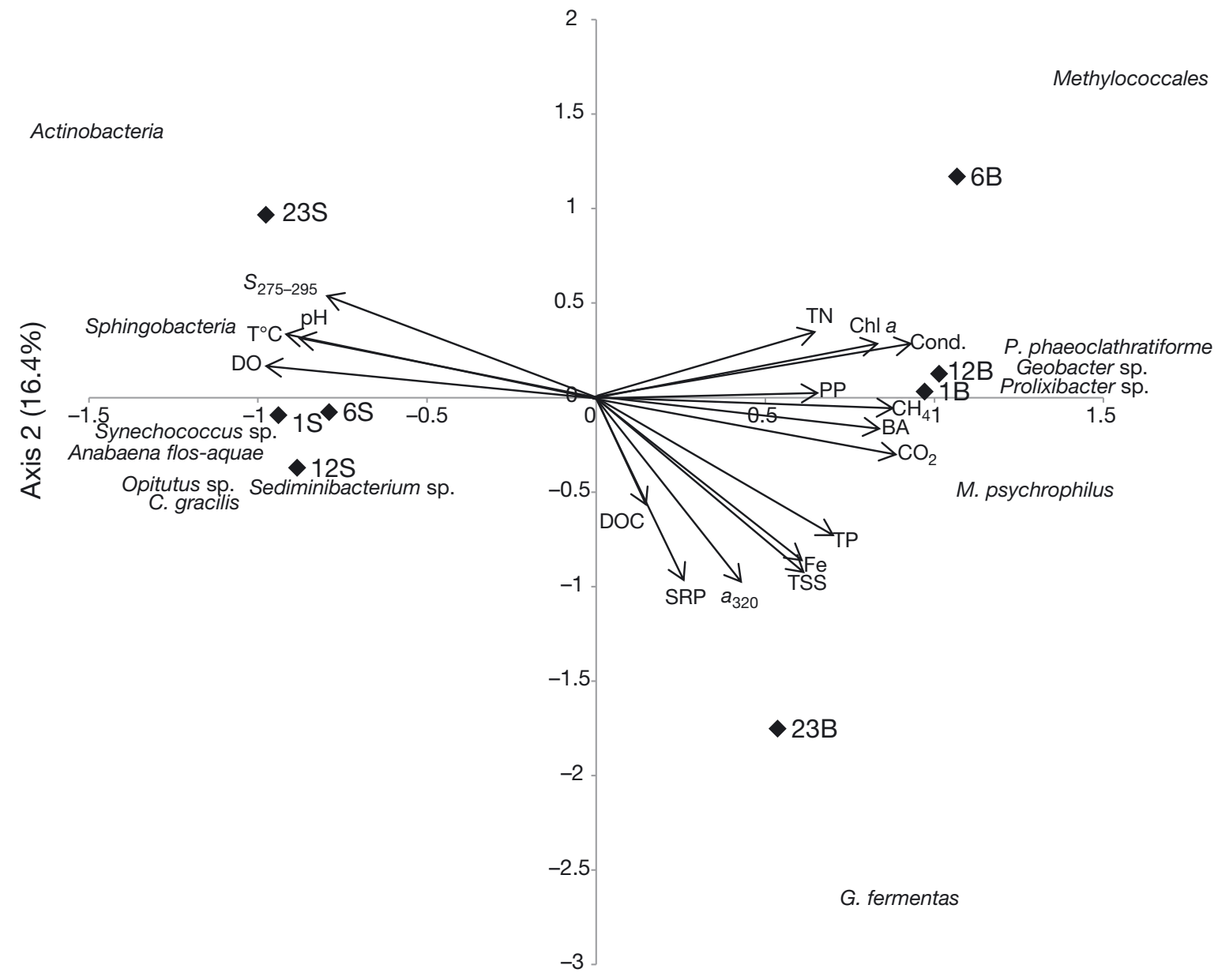

Axis 1 (19.6\%)

Fig. 4. Distribution of samples and important bacterial taxa according to bacterial communities and environmental gradients in a canonical correspondence analysis. S: surface; B: bottom. KWK are referred to by their identification number. Other abbreviations as in Table 1 
minibacterium. On the other side of these gradients, the group formed by the bottom samples from KWK1 and -12 was characterized by environmental conditions favoring or influenced by the sequences with matches to Pelodictyon, Geobacter, Prolixibacter, and Methylobacter. The bottom KWK-6 sample separated from the others apparently due to slightly lower $\mathrm{P}, \mathrm{Fe}$, and DOM, but especially by the presence of Methylococcales. The segregation of KWK-23 samples also seems to be determined by this set of environmental conditions ( $\mathrm{P}, \mathrm{Fe}$, and $\mathrm{DOM})$, and with the highest probability attributed to sequences related to Geothrix fermentans at the bottom, and Actinobacteria at the surface.

\section{DISCUSSION}

Bacterial cell concentrations, particularly in the bottom waters, with up to $38 \times 10^{6} \mathrm{cells} \mathrm{ml}^{-1}$, were 10 fold greater than reported from dystrophic (Allgaier \& Grossart 2006) and shallow humic lakes (Graham et al. 2004). Permafrost thaw ponds have been described as biologically productive systems (Squires et al. 2009, Laurion et al. 2010, Vincent et al. 2010); however, high concentrations of CDOM and suspended fine particles in these ponds decrease light penetration (Watanabe et al. 2011), limiting photosynthetic productivity, and the ponds tend to release inorganic carbon (Webster et al. 2008). At the same time, allochthonous carbon from thawing permafrost provides an additional source of organic matter and nutrients for heterotrophic microbes. In August, the 4 ponds were supersaturated in $\mathrm{CO}_{2}$ and $\mathrm{CH}_{4}$ at the surface, and the thermal stability in thaw systems promoted anoxia and production of GHGs, especially $\mathrm{CH}_{4}$ (Shirokova et al. 2009, Laurion et al. 2010) leading to even higher GHG concentrations in bottom waters. Despite a clear dominance of heterotrophic cells from flow cytometry counts, chl a concentrations appeared high, even near the bottom. Surface phytoplankton may have settled into the suboxic zone or alternatively, high chlorophyll concentrations could be from Chlorobi, since bacterial chlorophyll pigments have similar absorption/fluorescence spectra to chl a (Overmann \& Pfennig 1989, Antoniades et al. 2009).

\section{Surface bacterial assemblages}

Community composition of the surface and deeper waters was consistent with limnological characteristics. Two ponds, KWK-1 and -12, were typical fresh- waters, with low conductivity and warmer surface temperatures in summer, and contained a higher proportion of Betaproteobacteria, typical of freshwater (Hiorns et al. 1997, Van der Gucht et al. 2005), including a boreal humic lake (Peura et al. 2012). Bacteroidetes, related to Sediminibacterium, which is reported to produce $\mathrm{H}_{2} \mathrm{~S}$ (Qu \& Yuan 2008), were also found in both of these ponds and in KWK-6. Similar to microscopy reports (Dupont 2009), we found few Cyanobacteria in some of the ponds. While high phosphorus concentrations coupled with a stable water column could favor Cyanobacteria blooms, their growth in these highly turbid ponds is likely limited by light availability (Rahman et al. 2005). Indeed, Cyanobacteria were most common in KWK-6 with the lowest turbidity, followed by KWK-12 and KWK-1, and none detected from KWK-23, the most turbid pond. Overall, KWK-23 surface water bacterial community differed from the others, with more Actinobacteria related to the AcI lineage, which so far as known, is exclusively freshwater (Newton et al. 2007), including reports from a boreal lake (Peura et al. 2012).

\section{Hypolimnetic bacterial assemblages}

Hypolimnetic suboxic conditions likely persist for most of the year, since the water column turnover lasts only a few days in autumn (e.g. $10 \mathrm{~d}$ in 2009 for ponds KWK-1 and -12), while in spring it can be very short ( $3 \mathrm{~d}$ in 2008 for a pond similar to KWK-1; Laurion et al. 2010) or absent (KWK-1 and -12 in 2010). We found differences among ponds consistent with major biological differences. In ponds KWK-1 and -12, Chlorobi, which are often abundant in freshwater hypoxic hypolimnia (Taipale et al. 2009, Barberán \& Casamayor 2011, Comeau et al. 2012, Peura et al. 2012), were by far the most common sequences. Watanabe et al. (2011) estimated that $1 \%$ surface irradiance was between 1.3 and $2.7 \mathrm{~m}$ in these ponds, i.e. ranges providing sufficient light for Chlorobi, which are adapted to low light environments (Koblizek et al. 2006). The bacterial community of the KWK-6 hypolimnion was dominated by Gammaproteobacteria, with nearly $90 \%$ related to Methylobacter psychrophilus. $M$. psychrophilus-related clones were also the only representatives of Gammaproteobacteria in KWK-1 and -23 bottom waters. These methanotrophs are discussed in more detail below.

The hypolimnetic community of KWK-23 differed substantially from the other ponds, with high representation of Bacteroidetes most similar to Prolixibacter spp. (Fig. 2), which can produce acetate used in 
methanogenesis (Nozhevnikova et al. 1997). KWK-23 bottom water was also unusual by having a high proportion of Acidobacteria (ca. 20\%), also reported from a Siberian peat bog clone library (Dedysh et al. 2006). Other clones were associated with Geothrix fermentans that oxidizes acetate and short chain fatty acids to $\mathrm{CO}_{2}$ using $\mathrm{Fe}(\mathrm{III})$ as the sole electron acceptor (Lonergan et al. 1996). The presence of Fe cycling bacteria is suggestive, given the high Fe concentration in the bottom KWK-23. Finally we note that Peura et al. (2012) recently reported that the candidate division OD1 was the most common phylum in boreal suboxic-anoxic freshwaters, and has likely been underreported because commonly used primers including ours have poor matches to OD1 sequences, and the potential presence of OD1 in these northern Quebec waters is unresolved.

\section{Methanotrophs}

Methanotrophs, which oxidize dissolved $\mathrm{CH}_{4}$ to $\mathrm{CO}_{2}$, act as a dynamic biofilter (Kessler et al. 2011) undertaking a major role in GHG exchanges, and special attention was given to identify potential methanotrophic Bacteria. The clones related to methanotrophs represented ca. $20 \%$ of the KWK-6 clone library and ca. $10 \%$ in KWK-1 and -23, but were not detected in KWK-12, which had the highest measured $\mathrm{CH}_{4}$ concentrations among the ponds. However, Verrucomicrobia may be methanotrophic in extremely acidic environments (Dunfield et al. 2007), and were relatively abundant in KWK-12 communities. Overall, potential methanotrophs from these subarctic thaw ponds were phylogenetically diverse, with both type I and type II methanotrophs, suggesting capacity to oxidize $\mathrm{CH}_{4}$ under a variety of different environmental constraints.

$\mathrm{CH}_{4}$ oxidation depends on the oxygen availability (Frenzel et al. 1990, Wagner et al. 2003) and would be predicted to occur at the oxic-anoxic interface (Hanson \& Hanson 1996). Although we sampled bottom waters with a horizontal van Dorn bottle integrating about $20 \mathrm{~cm}$, Bacteria from a sharp chemocline may have mixed with the deeper samples or deep waters were not completely anoxic, despite the presence of green sulfur bacteria.

\section{Origins of best matches}

The ponds are surrounded by thick shrubs, sparse trees, and variable underlying peat (Bhiry et al. 2011,
Bouchard et al. 2011). Bacteria in the ponds could originate from the surrounding soils, or be transported by wind or rain (Harding et al. 2011). Typical freshwater flora would eventually be selected for at the surface of thaw ponds. Overall the combination of a short wind fetch (10 to $30 \mathrm{~m}$ ) and near-surface heating results in water columns that are highly stratified despite the shallow depth (1 to $4 \mathrm{~m}$ ) of the ponds (Laurion et al. 2010), and where heterotrophic metabolism would be favored since light is limiting for aerobic photosynthesis (Watanabe et al. 2011).

The majority of clones retrieved from thaw ponds had closest matches to bacteria from other freshwater environments, especially lakes. The apparent poor representation of bacteria from surrounding soils in thaw pond communities could be attributed to the very small drainage basin and long retention time for water in these systems (Crump et al. 2007), limiting the mass effect and favoring species selection by environmental factors.

\section{Limnological and bacterial community-based ordinations}

The ponds did not group by geographic space. At an extreme end, the 2 ponds geographically closest (ca. $10 \mathrm{~m}$ ), KWK-6 and -23, were limnologically the most distant. However, surface samples were separated from bottom waters, where relatively large quantities of organic matter, low light availability, cool temperatures and low or absent oxygen create a selective environment for microbes. The CCA and significance tests indicated that surface and bottom bacterial community compositions were also significantly different. The out-grouping of KWK-23S from the surface cluster showed that bacterial communities could differ between superficially similar environments, for example both KWK-1 and -23 were brown. On the other hand, 2 limnologically different environments, KWK-1B and -12B, had similar communities. The influence of environmental factors shaping bacterial communities was explored using a CCA (Fig. 4). In this constrained ordination, the sample positions were the same as in the CA, suggesting that the measured environmental variables explained most of the biological variation (Ramette 2007). Although the results should be interpreted with caution considering the low number of samples, some trends appeared. DO was an obvious difference between surface and bottom communities. Of interest was KWK-23, where both surface and bottom waters were outliers. The specific values of 
$S_{275-295}$, reflecting organic carbon lability (Helms et al. 2008), could be involved in shaping the KWK23S community including the presence of Actinobacteria. Factors such as $a_{320}, \mathrm{P}$, and Fe could be linked to the presence of sequences related to Geothrix fermentans, characteristic of the KWK-23B community.

These results highlight the great diversity of conditions found in thaw ponds, but suggest a role for particular events or succession of events that lead to distinct habitats. A larger number of ponds would be needed to discern any regional patterns driven by pond morphology, age, or catchment (Bouchard et al. 2011), which may result in different bacterial assemblages within a specific region (Logue \& Lindström 2008). As suggested by the origins of the best matches, community composition was mostly determined by the environmental conditions within the ponds and not by the surrounding environment. This study demonstrates remarkable diversity among ponds separated by only a few meters. Methanotrophs were conspicuous members of the pond bacterial communities and may mitigate $\mathrm{CH}_{4}$ emissions in this region. Further investigations of Bacteria but also Archaea are needed to assess the GHG response of these ecosystems facing global warming.

Acknowledgements. We thank F. Bouchard, B. Ginoux, C. Girard, T. Roiha, D. Sarrazin, and A. Warren for their assistance in the field; A. M. Comeau, A. D. Jungblut, M. Potvin, R. Terrado, and others in the Lovejoy lab for help in the laboratory and data analysis; I. Lavoie and M. Thaler for statistical advice; and 3 anonymous reviewers for their suggestions that improved the original manuscript. The Fonds Québécois de la Recherche sur la Nature et les Technologies support for the Centre for Northern Studies (CEN) is acknowledged. P.-G.R. received a postdoctoral research fellowship from the Government of Canada (Foreign Affairs and International Trade program of academic exchanges), and the research was funded by the Natural Sciences and Engineering Council of Canada (NSERC) Discovery Grants (I.L. and C.L.) and ArcticNet (I.L. and C.L.).

\section{LITERATURE CITED}

Allgaier M, Grossart HP (2006) Diversity and seasonal dynamics of Actinobacteria populations in four lakes in northeastern Germany. Appl Environ Microbiol 72: 3489-3497

Altschul SF, Gish W, Miller W, Myers EW, Lipman DJ (1990) Basic local alignment search tool. J Mol Biol 215:403-410

> Antoniades D, Veillette J, Martineau MJ, Belzile C and others (2009) Bacterial dominance of phototrophic communities in a High Arctic lake and its implications for paleoclimate analysis. Polar Sci 3:147-161

- Barberán A, Casamayor EO (2011) Euxinic freshwater hypolimnia promote bacterial endemicity in continental areas. Microb Ecol 61:465-472

Bhiry N, Delwaide A, Allard M, Bégin Y and others (2011) Environmental change in the Great Whale River region, Hudson Bay: five decades of multidisciplinary research by Centre d'études nordiques (CEN). Ecoscience 18: 182-203

Bouchard F, Francus P, Pienitz R, Laurion I (2011) Sedimentology and geochemistry of thermokarst ponds in discontinuous permafrost, subarctic Quebec, Canada. J Geophys Res 116:G00M04, doi:10.1029/2011JG001675

Breton J, Vallières C, Laurion I (2009) Limnological properties of permafrost thaw ponds in northeastern Canada. Can J Fish Aquat Sci 66:1635-1648

Comeau AM, Harding T, Vincent WF, Lovejoy C (2012) Vertical distribution of microbial communities in a perennially-stratified Arctic lake with saline, anoxic bottom waters. Sci Rep 2:604, doi:10.1038/srep00604

Crump RC, Adams HE, Hobbie JE, Kling GW (2007) Biogeography of bacterioplankton in lakes and streams of an Arctic tundra catchment. Ecology 88:1365-1378

Dedysh SN, Pankratov TA, Belova SE, Kulichevskaya IS, Liesack W (2006) Phylogenetic analysis and in situ identification of Bacteria community composition in an acidic Sphagnum peat bog. Appl Environ Microbiol 72: 2110-2117

DeSantis TZ, Hugenholtz P, Larsen N, Rojas M and others (2006) Greengenes, a chimera-checked 16S rRNA gene database and workbench compatible with ARB. Appl Environ Microbiol 72:5069-5072

> Díez B, Pedrós-Alió C, Massana R (2001) Study of genetic diversity of eukaryotic picoplankton in different oceanic regions by small-subunit rRNA gene cloning and sequencing. Appl Environ Microbiol 67:2932-2941

> Dunfield PF, Yuryev A, Senin P, Smirnova AV and others (2007) Methane oxidation by an extremely acidophilic bacterium of the phylum Verrucomicrobia. Nature 450: 879-882

Dupont C (2009) Diversité microbienne des mares générées par la fonte du pergélisol en régions arctique et subarctique. MSc thesis, Université du Québec

Felsenstein J (1989) PHYLIP - phylogeny inference package (version 3.2). Cladistics 5:164-166

> Frenzel P, Thebrath B, Conrad R (1990) Oxidation of methane in the oxic surface layer of a deep lake sediment (Lake Constance). FEMS Microbiol Ecol 73: $149-158$

- Graham JM, Kent AD, Lauster GH, Yannarell AC, Graham LE, Triplett EW (2004) Seasonal dynamics of phytoplankton and planktonic protozoan communities in a northern temperate humic lake: diversity in a dinoflagellate dominated system. Microb Ecol 48:528-540

> Gundersen K, Bratbak G, Heldal M (1996) Factors influencing the loss of bacteria in preserved seawater samples. Mar Ecol Prog Ser 137:305-310

- Hamady M, Lozupone C, Knight R (2010) Fast UniFrac: facilitating high-throughput phylogenetic analyses of microbial communities including analysis of pyrosequencing and PhyloChip data. ISME J 4:17-27

Hammer Ø, Harper DAT, Ryan PD (2001) PAST: paleontological statistics software package for education and data analysis. Palaeontol Electron 4:1-9

Hanson RS, Hanson TE (1996) Methanotrophic bacteria. Microbiol Rev 60:439-471

Harding T, Jungblut AD, Lovejoy C, Vincent WF (2011) Microbes in High Arctic snow and implications for the 
cold biosphere. Appl Environ Microbiol 77:3234-3243

> Helms JR, Stubbins A, Ritchie JD, Minor EC, Kieber DJ, Mopper K (2008) Absorption spectral slopes and slope ratios as indicators of molecular weight, source, and photobleaching of chromophoric dissolved organic matter. Limnol Oceanogr 53:955-969

> Hiorns WD, Methe BA, Nierzwicki-Bauer SA, Zehr JP (1997) Bacterial diversity in Adirondack mountain lakes as revealed by $16 \mathrm{~S}$ rRNA gene sequences. Appl Environ Microbiol 63:2957-2960

Huber T, Faulkner G, Hugenholtz P (2004) Bellerophon: a program to detect chimeric sequences in multiple sequence alignments. Bioinformatics 20:2317-2319

Jeffrey SW, Welschmeyer NA (1997) Spectrophotometric and fluorometric equations in common use in oceanography. In: Jeffrey SW, Mantoura RFC, Wright SW (eds) Phytoplankton pigments in oceanography: guidelines to modern methods. Monographs on oceanographic methodology 10. UNESCO Publishing, Paris, p 597-615

> Kessler JD, Valentine DL, Redmond MC, Du M and others (2011) A persistent oxygen anomaly reveals the fate of spilled methane in the deep Gulf of Mexico. Science 331: 312-315

Koblizek M, Falkowski PG, Kolber ZS (2006) Diversity and distribution of photosynthetic bacteria in the Black Sea. Deep-Sea Res II 53:1934-1944

Larkin MA, Blackshields G, Brown NP, Chenna R and others (2007) Clustal W and Clustal X version 2.0. Bioinformatics 23:2947-2948

Laurion I, Vincent WF, MacIntyre S, Retamal L, Dupont C, Francus P, Pienitz R (2010) Variability in greenhouse gas emissions from permafrost thaw ponds. Limnol Oceanogr 55:115-133

Logue JB, Lindström ES (2008) Biogeography of bacterioplankton in inland waters. Freshw Rev 1:99-114

> Loiselle SA, Bracchini L, Dattilo AM, Ricci M, Tognazzi A, Rossi C (2009) Optical characterization of chromophoric dissolved organic matter using wavelength distribution of absorption spectral slopes. Limnol Oceanogr 54: 590-597

> Lonergan DJ, Jenter HL, Coates JD, Phillips EJP, Schmidt TM, Lovley DR (1996) Phylogenetic analysis of dissimilatory Fe(III)-reducing bacteria. J Bacteriol 178:2402-2408

Lorke A, Peeters G (2006) Toward a unified scaling relation for interfacial fluxes. J Phys Oceanogr 36:955-961

> McGuire AD, Anderson LG, Christensen TR, Dallimore S and others (2009) Sensitivity of the carbon cycle in the Arctic to climate change. Ecol Monogr 79:523-555

Newton RJ, Jones SE, Helmus MR, McMahon KD (2007) Phylogenetic ecology of the freshwater Actinobacteria acI lineage. Appl Environ Microbiol 73:7169-7176

Nozhevnikova AN, Holliger C, Ammann A, Zehnder AJB (1997) Methanogenesis in sediments from deep lakes at different temperatures $\left(12-70^{\circ} \mathrm{C}\right)$. Water Sci Technol 36: 57-64

Nush EA (1980) Comparison of different methods for chlorophyll and phaeopigment determination. Arch Hydrobiol (Beih Ergebn Limnol) 14:14-39

> Overmann J, Pfennig N (1989) Pelodictyon phaeoclathratiforme sp. nov., a new brown-colored member of the Chlorobiaceae forming net-like colonies. Arch Microbiol 152:401-406

Parry ML, Canziani OF, Palutikof JP, van der Linden PJ, Hanson CE (eds) (2007) Climate change 2007: impacts, adaptation and vulnerability. Contribution of Working
Group II to the Fourth Assessment Report of the Intergovernmental Panel on Climate Change. Cambridge University Press, Cambridge

Payette S, Delwaide A, Caccianiga M, Beauchemin M (2004) Accelerated thawing of subarctic peatland permafrost over the last 50 years. Geophys Res Lett 31:L18208, doi: 10.1029/2004GL020358

Peura S, Eiler A, Bertilsson S, Nykänen H, Tiirola M, Jones RI (2012) Distinct and diverse anaerobic bacterial communities in boreal lakes dominated by candidate division OD1. ISME J 6:1640-1652

Phelps AR, Peterson KM, Jeffries MO (1998) Methane efflux from high latitude lakes during spring ice melt. J Geophys Res 103:29029-29036, doi:10.1029/98JD00044

Pienitz R, Doran PT, Lamoureaux SF, Vincent WF (2008) Origin and geomorphology of lakes in the polar regions. In: Vincent WF, Laybourn-Parry J (eds) Polar lakes and rivers: limnology of Arctic and Antarctic aquatic ecosystems. Oxford University Press, Oxford, p 25-41

$>$ Qu JH, Yuan HL (2008) Sediminibacterium salmoneum gen. nov., sp. nov., a member of the phylum Bacteroidetes isolated from sediment of a eutrophic reservoir. Int J Syst Evol Microbiol 58:2191-2194

Rahman AKM, Al Bakri D, Ford P, Church T (2005) Limnological characteristics, eutrophication and cyanobacterial blooms in an inland reservoir, Australia. Lakes Reserv Res Manag 10:211-220

> Ramette A (2007) Multivariate analyses in microbial ecology. FEMS Microbiol Ecol 62:142-160

Schloss PD, Westcott SL, Ryabin T, Hall JR and others (2009) Introducing mothur: open-source, platform-independent, community-supported software for describing and comparing microbial communities. Appl Environ Microbiol 75:7537-7541

> Schuur EA, Vogel JG, Crummer KG, Lee H, Sickman JO, Osterkam TE (2009) The effect of permafrost thaw on old carbon release and net carbon exchange from tundra. Nature 459:556-559

Shakun JD, Clark PU, He F, Marcott SA and others (2012) Global warming preceded by increasing carbon dioxide concentrations during the last deglaciation. Nature 484: 49-54

- Shirokova LS, Pokrovsky OS, Kirpotin SN, Dupre B (2009) Heterotrophic bacterio-plankton in thawed lakes of the northern part of Western Siberia controls the $\mathrm{CO}_{2}$ flux to the atmosphere. Int $\mathrm{J}$ Environ Stud 66:433-445

> Squires MM, Lesack LFW, Hecky RE, Guildford SJ, Ramlal P, Higgins SN (2009) Primary production and carbon dioxide metabolic balance of a lake rich arctic river floodplain: partitioning of phytoplankton, epipelon, macrophyte, and epiphyton production among lakes on the Mackenzie Delta. Ecosystems 12:853-872

Stainton MP, Capel MJ, Armstrong FAJ (1977) The chemical analysis of freshwater, 2nd edn. Can Fish Mar Serv Misc Spec Publ 25:1-166

Striegl RG, Kortelainen P, Chanton JP, Wickland KP, Bugna GC, Rantakari M (2001) Carbon dioxide partial pressure and ${ }^{13} \mathrm{C}$ content of north temperate and boreal lakes at spring ice melt. Limnol Oceanogr 46:941-945

> Taipale S, Jones RI, Tiirola M (2009) Vertical diversity of bacteria in an oxygen-stratified humic lake, evaluated using DNA and phospholipid analyses. Aquat Microb Ecol 55:1-16

Tarnocai C, Canadell JG, Mazhitova G, Schuur EAG, Kuhry 
P, Zimov S (2009) Soil organic carbon pools in the northern circumpolar permafrost region. Global Biogeochem Cycles 23:GB2023, doi:10.1029/2008GB003327

ter Braak CJF, Smilauer P (1998) CANOCO reference manual and user's guide to Canoco for Windows: software for canonical community ordination (version 4). Microcomputer Power, Ithaca, NY

Van der Gucht K, Vandekerckhove T, Vloemans N, Cousin S and others (2005) Characterization of bacterial communities in four freshwater lakes differing in nutrient load and food web structure. FEMS Microbiol Ecol 53:205-220

Vincent WF, Lemay M, Barnard C (eds) (2010) Impacts of environmental change in the Canadian coastal Arctic: a compendium of research conducted during ArcticNet Phase I (2004-2008). ArcticNet, Quebec

> Wagner D, Kobabe S, Pfeiffer EM, Hubberten HW (2003) Microbial controls on methane fluxes from a polygonal tundra of the Lena Delta, Siberia. Permafrost Periglac Process 14:173-185

Walter KM, Zimov S, Chanton JP, Verbyla D, Chapin FS

Editorial responsibility: Eva Lindström,

Uppsala, Sweden
(2006) Methane bubbling from Siberian thaw lakes as a positive feedback to climate warming. Nature 443:71-75

Walter KM, Chanton JP, Chapin FS, Schuur EAG, Zimov SA (2008) Methane production and bubble emissions from arctic lakes: isotopic implications for source pathways and ages. J Geophys Res 113:G00A08, doi:10.1029/2007 JG000569

Wang Q, Garrity GM, Tiedje JM, Cole JR (2007) Naive Bayesian classifier for rapid assignment of rRNA sequences into the new bacterial taxonomy. Appl Environ Microbiol 73:5261-5267

> Watanabe S, Laurion I, Chokmani K, Pienitz R, Vincent WF (2011) Optical diversity of thaw ponds in discontinuous permafrost: a model system for water color analysis. J Geophys Res 116:1-17, doi: 10.1029/2010JG001380

> Webster KE, Soranno PA, Cheruvelil KS, Bremigan MT and others (2008) An empirical evaluation of the nutrientcolor paradigm for lakes. Limnol Oceanogr 53:1137-1148

Zimov SA, Voropaev YV, Semiletov IP, Davidov SP and others (1997) North Siberian lakes: a methane source fuelled by Pleistocene carbon. Science 277:800-802

Submitted: June 5, 2012; Accepted: April 17, 2013 Proofs received from author(s): June 16, 2013 